\title{
Transatlantica
}

Revue d'études américaines. American Studies Journal

\section{From Performance to Participation: The Origins of the Fit Nation}

\section{Natalia MehIman Petrzela}

\section{(2) OpenEdition}

\section{Journals}

Electronic version

URL: https://journals.openedition.org/transatlantica/16318

DOI: 10.4000/transatlantica. 16318

ISSN: 1765-2766

\section{Publisher}

Association française d'Etudes Américaines (AFEA)

\section{Electronic reference}

Natalia Mehlman Petrzela, "From Performance to Participation: The Origins of the Fit Nation",

Transatlantica [Online], 2 | 2020, Online since 01 March 2021, connection on 31 January 2023. URL: http://journals.openedition.org/transatlantica/16318; DOl: https://doi.org/10.4000/transatlantica. 16318

This text was automatically generated on 31 January 2023.

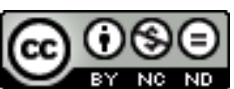

Creative Commons - Attribution-NonCommercial-NoDerivatives 4.0 International - CC BY-NC-ND 4.0 https://creativecommons.org/licenses/by-nc-nd/4.0/ 


\title{
From Performance to Participation: The Origins of the Fit Nation
}

\author{
Natalia Mehlman Petrzela
}

\section{Physical Fitness as Performance of "Civilized" Whiteness}

1 His defined muscles carefully powdered to more closely resemble the Italian statues that inspired him as a formerly "pale, frail, and delicate" boy, Eugen Sandow perched atop a black velvet box in scanty silk shorts. Posing before awestruck nightly audiences of nearly six thousand, the Prussian-born strongman reveled in the enthusiasm of his relatively uninhibited American hosts at the 1893 World's Fair, visited by nearly 26 million. Timid at first, women lined up to run their gloved hands over the flexed physique of "The World's Most Perfect Man," swooning at his winking invitation to "come feel how hard these muscles are," and reduced to "nervous trembling" upon touching his rippling body (Waller 93). Indefatigable showman Florenz Ziegfeld had discovered that in a moment of social and political division, Sandow's sculpted physique proved a universally appealing attraction.

2 Not that Sandow himself imagined the physical exercise to which he was so devoted as a great equalizer. On the contrary, intentionally cultivating one's strength separated him and fellow physical culturists from savages who possessed mere brute strength. When Sandow docked in New York Harbor on a blazing hot day on his way to the Fair, he immediately found the more socioeconomically fluid and racially diverse United States-"that great country of wonderful records"-a new arena to show off his strong body, but also the cultural and moral superiority it conferred (Sandow 123).

3 It took less than an hour on American shores for Sandow to find his first contest, with the African American bellhop who carried Sandow's bags, but who also rolled a cigarette and took a deep, exaggerated drag in the strongman's handsomely appointed quarters. Sandow instructed the bellhop to shine his shoes, but he instead sprawled on the sofa, lit a second cigarette, and announced: “We don't do that in America." This 
impudence, in Sandow's esteem, was "too much for white flesh and blood to bear." He threatened to report the "boy" to the manager, and the bellhop "squared up" for a fight.

4 Enraged, Sandow grabbed his lapels and dangled him over the sixteenth-floor banister. The "shouts and screams" drew a crowd. Thanks to his own restraint, Sandow assures his reader, tragedy was averted: he was sure the bellhop's jacket could withstand the strain. Once satisfied the shaken bellhop had accepted the European's superiority, Sandow set him down and assured him that "if he attempted his impertinences again, I would bring him to the same spot and open it. And a drop of sixteen floors would not be good even for nigger boys who smoked cigarettes in private rooms and affected to be indignant at the suggestion they should clean a visitor's boots" (Sandow 125).

5 Consciously cultivating his strength and wielding it with control was key to how Sandow distinguished himself from, and exercised power over, the louts he disdained as possessing insufficient mastery over their physicality. Back in London, he had hired a hulking "Goliath" he found in the German countryside to take the stage before awestruck crowds, but the show always concluded with the physically slighter, but intelligently trained, Sandow overpowering this oafish "mere breaker of stones" (Sandow 104). Similarly, African Americans were widely stereotyped as superhumanly strong, but also uncontrolled in their appetites and impulses. In emphasizing how he developed his strength for self-improvement rather than labor; resisting the urge to let the bellhop plummet to his death; and also abstaining from alcohol and tobacco, Sandow strove to link the cultivation of strength to an enviable capacity for discipline and self-possession antithetical to Blackness.

Figure 1: Eugen Sandow flexes in Roman sandals and fig leaf, 1894. Library of Congress. www.loc.gov/resource/cph.3b45831. Accessed 15 February 2021.

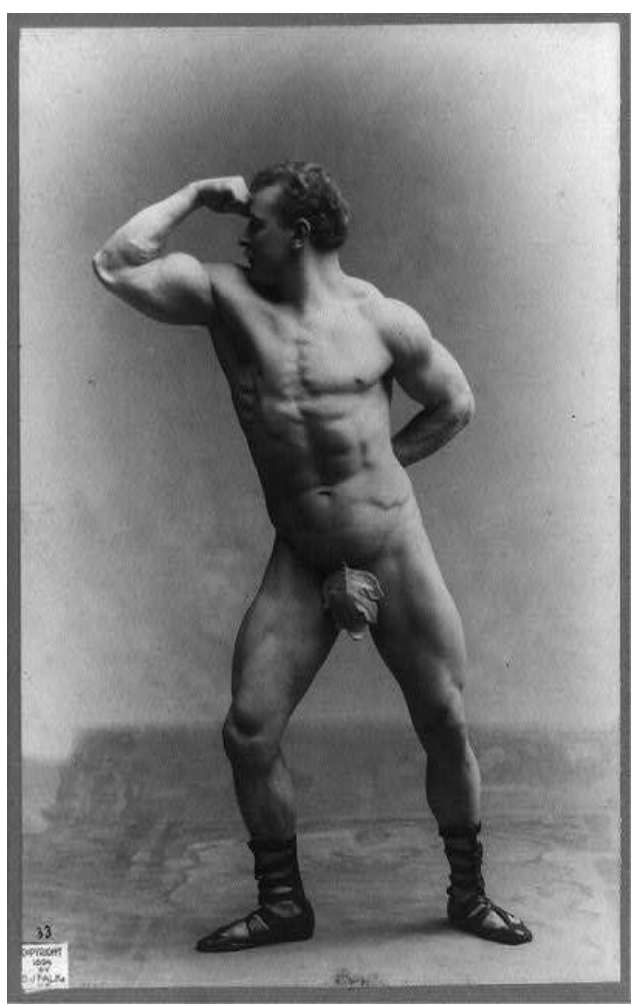


6 Early strongmen like Sandow are often remembered as the pioneers of contemporary American fitness culture, and in some ways they established our understanding of exercise as a pursuit of the affluent, disciplined, and attractive. Throughout colorful careers that in some cases stretched into the postwar era, Sandow and his telegenic, entrepreneurial peers like Bernarr MacFadden and Charles Atlas indeed spread these associations through the shows, magazines, and consumer products that first displayed fit bodies and instructed how to achieve them. But the similarities end there.

7 In this era, the deliberate pursuit of fitness and its attendant muscular aesthetic was much more performative than participatory. Crowds gathered to gape at these strapping exemplars of strength, but it would be decades before any significant public would aspire to lift, or look, like them. Thanks in part to these early enthusiasts, and to a set of political, cultural, and economic circumstances that enabled their entrepreneurship, by the 1950s, the fit ideal began to move off the proverbial stage toward the central role it plays in modern American life. This essay explains how the pursuit of exercise evolved from a strange, suspicious subculture characterized by individual performance in the late nineteenth and early twentieth centuries to a more participatory realm germinated at Muscle Beach in the 1940s and 1950s. This transformation established the foundation of today's "fit nation," a culture unimaginable in Sandow's era, in which the pursuit of exercise is valorized as a virtuous ideal-if not one equitably accessible along the lines of gender and race. Indeed, while this evolution represents an expansion of fitness culture, its inclusiveness was constrained by its roots in an ideology that defined "civilized" fitness as white and male (Bederman).

8 Early strongmen labored to establish the legitimacy of bodily cultivation. Indeed, Sandow likely boasts so proudly of the European aristocrats and affluent Americans who showed up to his appearances at symphony halls and theaters dripping with jewels and offering lavish gifts, because strongmen were more likely to be featured alongside bearded ladies and Siamese twins at seedy carnivals and circuses. MacFadden was less successful at avoiding such associations. In 1905, just as the doors to his second annual Physical Culture Exhibition were about to open at Madison Square Garden, the police, summoned by anti-obscenity crusader Anthony Comstock, blocked the doors and threatened to turn crowds away from this "indecent exhibition" ("Comstockery vs. MacFaddenism"). Though the 1904 competition had featured men and women posing like classical statues, such "carnality" seemed obscene to Comstock and his contemporaries.

In nearby Brooklyn, another strongman attempted to make his way in a country skeptical of the pursuit of fitness. Born Angelo Siciliano in Calabria, Italy, the scrawny boy who became Charles Atlas was so impressed by the classical sculptures of Hercules, Apollo, and Zeus at the Brooklyn Museum, he decided he wanted to resemble them. Young Angelo began lifting weights, and found a job as a sideshow strongman, lying on a bed of nails, daring passersby to walk across his chest. Between shifts, he flexed on the Coney Island boardwalk, hoping to get noticed for better paying gigs. Those dreams materialized in 1916, when he was booked to pose for sculptors and painters. Before long, New York City statues bore the familiar faces of George Washington and Alexander Hamilton but atop bodies modeled on Atlas's strapping physique. Pedestrians strolling through Washington Square Park or Washington, DC, encountered more subtle inspiration by a physically fit form than at a circus or sideshow (Black). 
Atlas soon broke into another echelon of fame, posing in MacFadden's international Physical Culture and in 1922 dubbed "The World's Most Perfectly Developed Man" before a packed Madison Square Garden audience. Though no longer banned as pornographic, in the first quarter of the twentieth century, fit bodies were extraordinary entities to be analyzed and admired on distant pedestals, rather than emulated.

The experiences of the far fewer strongwomen of the era clarify the limits of this early fandom. "Lady Hercules" Katie Brumbach, later known as "The Great Sandwina" when she bested Sandow in 1902 by single-handedly raising three hundred pounds overhead (he could only reach his chest), proves the point. Born into a Prussian circus family, Sandwina performed feats of strength even as a toddler, taking on wrestling challenges for a price at her father's behest. After a particularly feisty match, she locked eyes with the man she had pinned to the floor and, as they relayed in many later interviews, they were instantly enamored. The two emigrated to America and struggled to make a living, performing with tiny vaudeville troupes in small cities like Syracuse and Newport before returning home to try their luck in France and Germany (Todd). In 1907, Sandwina got her big break: circus impresario John Ringling recruited the troupe to join the American tour, where he knew a public ever more fascinated with strength would thrill at how this member of the "weaker sex" tossed around her husband and other men half her size.

11 Sandwina became Ringling's main attraction, and he arranged for her to stand before the press in a public examination by a dozen doctors under the Madison Square Garden spotlights. This spectacle established both that "she is a perfect woman by all accepted standards" and her bizarre role in the American press as a superhuman specimen (Todd 53). "As she swings gracefully into the arena on supple, slender, silk encasedlimbs," one typically flattering profile rhapsodized, "your vision seems to dilate a bit, your eyes adjust to the magnified but perfect womanly proportions and she is more like a new and shining statue of an heroic Venus than the antique knotted and gnarled God of strength" (Martyn). The positive cast of such descriptions notwithstanding, the abundance of nonhuman analogies to describe "the titaness"-mice, the Sphinx, panthers, even from a woman journalist reluctant to make "yet another comparison" between women and "the cat tribe"-highlighted the strangeness of strong women (Carew). Notably, the working-class women who participated in the exhibition boxing subculture, by contrast, inspired no such wonder, and were either ignored or treated like "physical freaks and sexual objects" (Rouse 24, 35). 
Figure 2: "The Lady Hercules. Katie Sandwina," n.d. Library of Congress. tile.loc.gov/storageservices/service/pnp/ggbain/06800/06840v.jpg. Accessed 15 February 2021.

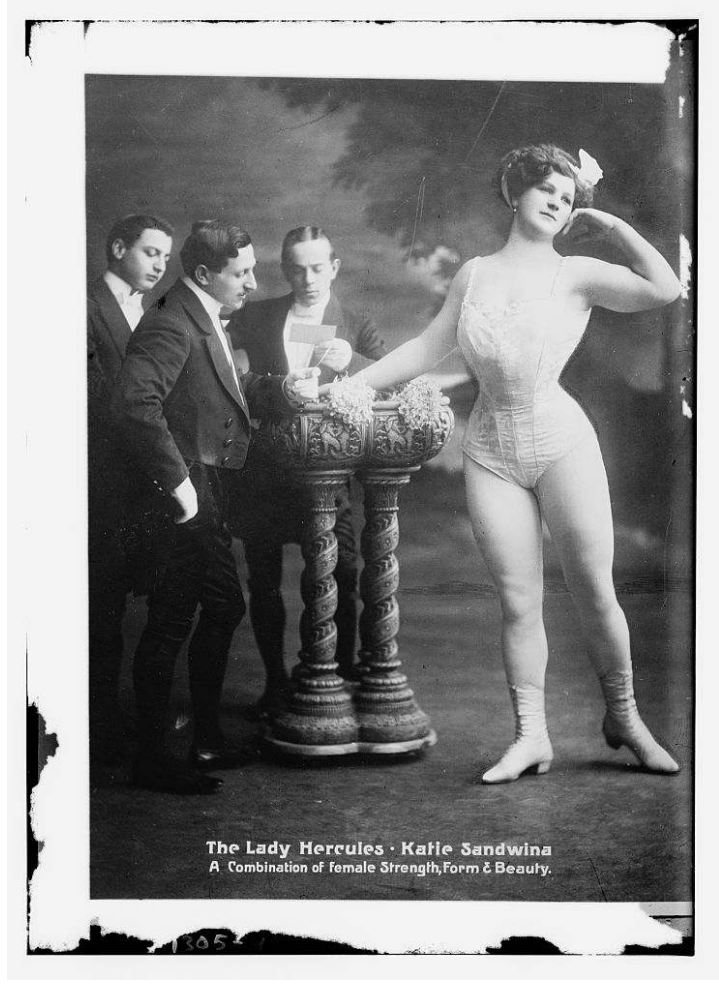

Against a backdrop of intensifying organization for women's suffrage, the acts the "Iron-Queen" performed over the nearly half century she traveled with Barnum and Bailey allowed men and women alike to project their emotions about changing gender dynamics onto this giantess who scooped her husband up in one powerful arm (Hulls). Such topsy-turviness bred speculation about the Sandwinas' sex life, but also sparked fantasies about the world beyond their bedroom. "If only all women were Sandwinas!" proclaimed the caption of a cartoon series in which otherwise prim ladies spanked their husbands over their knees and gallantly offered the weaker sex-men-seats. The journalist expressly connected Sandwina to politics: "Certainly, if we were all strong as Sandwina, there would be an end to that ancient, reliable, very tiresome argument of the anti-suffragists that women should not have the right to vote because they cannot defend that right, serving on the army, the police force, and all that" (Martyn). To those who cherished the social order, of course, Sandwina might thrill in a circus ring, but outside represented a threat.

As much as her physical stature and stunts challenged assumptions about female frailty, Sandwina often reassured audiences of her normalcy-which meant delicacy. She posed in frills and ruffles thronged by tuxedoed men, as if to emphasize that her muscular body made her no less a lady. The St. Louis Dispatch journalist who fantasized about Sandwina inspiring suffragists was disappointed to learn that the strongwoman cooked and cleaned with delight, and looked down on "American haus fraus" who "cook too quickly and whose husbands eat too fast." Hardly the voice of the sisterhood this writer had imagined, Sandwina barely spoke while her husband celebrated her devotion to domestic labor because "she likes to do it." The crestfallen journalist reported "Lady Hercules" only smiled as her husband unmistakably insulted the activists resisting the idea that women did not belong at work or at the polls: "My wife 
would never appear in public except as she does in her profession. She likes best the family life" (Martyn).

So if Sandwina was primarily perceived as a curiosity for her enormous strength-in one act, she hoisted a 1,200-pound cannon across her shoulders, and in another had multiple men lie across a bridge built across her torso-she also deployed her fortitude to be more than a freak show favorite. In 1912, she was elected the vice president of the Barnum \& Bailey Circus Women's Equal Rights Society, and the New York Times reported on how, in contrast to angry men who snatched their wives and daughters away from the meeting, Sandwina's husband stood by respectfully ("Enlist Suffragists"). Specifically in the struggle for suffrage, but also in generally questioning dominant assumptions about women, she built on a growing appreciation, if among a relatively select group of physical culturists, that "the frail, delicate, wax-doll standard of beauty in a woman is no longer in vogue," as declared one 1903 article in MacFadden's women's magazine, Beauty and Health ("Untitled" 21).

Her unconventional aesthetic made her very existence a challenge to gender norms, and she deftly navigated this reality. Demure and deferential in the presence of her husband and children, Sandwina shared openly about her sexual appetites in a 1910 interview with a German newspaper in a way usually unspeakable for respectable women: "What shall I say? Men are like air to me, you can't live without them. Every now and then I breathe good fresh air, you know" (Hulls). As scholars Patricia Vertinsky and David Chapman have argued, Sandwina's career in an era when strength and femininity were thought to be mutually exclusive laid a foundation for the muscular women who built on her legacy "to change the order of things, to stare back at the objectifying gaze, refashion femininity, and add a voice to feminist struggles for equality and self-realization" (23). She challenged the notion of "the eternally wounded woman," but sufficiently performed conventional femininity to leave the archetype of white, male strength intact (Vertinsky).

The celebrations of her "perfect body" and "ideal form" do reflect a surprisingly capacious aesthetic ideal, given persistent stereotypes that muscular women are mannishly unattractive. Just as the American suffrage movement challenged gender norms while upholding racial hierarchy, however, these paeans to Sandwina's beauty left unchallenged the idea that a defining aspect of her beauty was not only her proportions, "just under a magnifying glass," but her whiteness (Jones). Hardly a positive article failed to commend her "Bavarian stock," an all but explicit reference to the system that placed whites of Germanic and Nordic extraction atop what was accepted as biologically determined order. In general, advocates of white women developing their strength presumed that their problem was "weakness," "nervousness," and seeking beauty in superficial fashion, rather than in developing the body beneath such finery. Working women of color, less likely to have the privilege to lie about wasting away were usually acknowledged only by contrast. Making this racist hierarchy clear, MacFadden, for example, emphasized the "duty" of (white) women to train toward "superb womanhood," as opposed to naturally hardier "peasants" and "squaws" (21).

17 Historian Jan Todd, herself ranked strongest woman in the world in the 1970s, compared the difference between one newspaperman's description of "Venus" Sandwina-"positively the most commanding beauty I have seen staged in years"-and his estimation of a fellow performer, a Japanese tightrope walker: "a chubby Jap girl 
with stubby legs, knotted and gnarled muscles, like an old-time ballet premiere's" (Todd 32). Black women were almost entirely excluded from circus labor, and black men only worked onstage in occasional sideshows like Barnum's "What is It?" tent in roles like "monkey-men." The exoticization of strong white bodies is undeniable, but of a different magnitude than the dehumanization of African Americans, as an 1892 crash of a circus train crystallized. Tallying his losses, the owner cruelly exclaimed: "Just think, fourteen of my best horses killed and every one of those darkies saved!" (Childress 176).

\section{The Origins of Exercise as Virtue}

Circus performers were extraordinary by definition, but the particular popularity of strength acts in the late nineteenth and early twentieth centuries arose from an emerging enthusiasm for exercise as redemption among everyday people in the age of industrialization. On the one hand, this was no turn-of-the-century invention. Those Greek and Roman statues that so inspired Atlas and Sandow harkened from a historical moment when regular exercise, at least for men, was considered worthy and ennobling for the self and the civic sphere.

In the antebellum United States, the few boosters of regular exercise were physicians, educators, and social reformers who imported European ideas inspired by a mythic ideal of classical Greece and Rome. But even those who advocated for "sailing, swinging, and riding in carriages or horseback" in addition to walking did so primarily because they brought people out of growing cities "forth into the fields" and the "open air" (Green 84). Except for young children, who were encouraged to engage in physical play and sport, exercise itself to promote health and beauty was far less popular than ventilation strategies to prevent "bad air" illnesses like "colds, coughs, and consumption" (Green 85-87).

A wave of German immigration after 1848 prompted a brief romance with gymnastics and calisthenics, especially among educators who substantially modified more "violent" forms to suit girls' delicate constitutions and to cultivate an "able-bodied womanhood" (Verbrugge, 1998). These reformers applauded how these programs could be completed at school, the gymnasium, or home, increasing the likelihood participants would consistently avoid weakness and idleness. Exercising gently at home also allowed women to escape not only biological, but also environmental obstacles to the active life. Explaining why white southern women rode horses "only occasionally," a 1931 history of sport reasoned, was "because the carriage with its negro coachman was so omnipresent" (Manchester 135). Indoor exercise eliminated the presence of such perceived threats to white womanhood.

21 Exercise could also be godly, claimed Protestants who linked even gentle calisthenics to virtuous discipline of the flesh. The appearance of the body, historian R. Marie Griffith has shown, outwardly reflected spirituality; strong, cultivated bodies signaled health and virtue (58). This outlook melded with a secular scientific establishment that embraced phrenology, the idea that intelligence was discernible by the shape of one's skull. By the late nineteenth century, "Muscular Christianity" connecting morality, masculinity, and muscles attained some cultural currency. President Theodore Roosevelt famously linked "the strenuous life" with national strength, ideas to which 
he was first introduced by his Protestant parents as a sickly child, scarcely able to enact these ideals but readily absorbing the ideology (Green).

But most Americans were resistant to militaristic, rigorous German programs, and even a calisthenics advocate like Godey's Lady's Book editor Sarah Josepha Hale qualified her endorsement of these pastimes, cautioning that "exercises of this sort should never be insisted on once they grow irksome" (Green 91). The limits of this incipient enthusiasm for exercise are clear in Massachusetts, home to the country's most elaborate antebellum school system, where in 1842, only 416 children were enrolled in health classes as compared to ten thousand in history, two thousand in algebra, and fifteen hundred in bookkeeping (Green 89). Absent a major sensibility-or policy-shift, regular exercise would remain a preoccupation of the few.

For decades, the regular, deliberate pursuit of exercise outside of organized sports was a marginal, even suspicious pursuit in an age in which a fat body was widely viewed as a positive sign of affluence. A century ago, to appear to be a "fat cat" or "lady of leisure" projected enviable wealth and success. As late as the 1880s, Amy Erdman Farrell writes, "fatness was often linked to a generalized sense of prosperity, distinction, and high status. The corpulence itself was not represented as bad, but rather was a sign of how much the rich person had" (27).

Fat gentlemen's clubs, for example, thrived until the 1920s. In 1904, The Boston Globe reported on a joyous, biannual gathering that packed Hale's Tavern "full of bulbous and overhanging abdomens and double chins," while the locals were "mostly bony and angular, [staring] with envy at the portly forms and rubicund faces which have arrived on every train" (Basu). Even one 1870 article criticizing such associations was revealing in its critique. The men who paraded through New York City on horseback were not objectionable because they were grotesque, but because they excluded those who lacked formidable physical frames and yearned to participate in their "sylvan retreat." As the journalist put it:

A well-disposed fat man-and few fat men are other than kindly-can dispense happiness and jollity to a hundred of the less fortunate of his fellow-beings, and why should all these reservoirs of cheer be compacted together, in churlish if majestic isolation, while the comparatively fleshless outer world goes sorrowing on? ("Apotheosis of Corpulence" 4)

Fatness, if expressed as white male affluence, could be aspirational.

A very different sylvan retreat and its comparatively chilly reception make the point. When Bernarr MacFadden secured 1,900 acres of unspoiled land in Spotswood, New Jersey, to found a colony devoted to outdoor exercise and natural foods, he imagined his followers-about two hundred joined-living free from "the saloon, drug store, tobacco shop, and other vices." But in 1905, this modest, even moralistic proposition inspired intense skepticism among neighbors. For one, MacFadden reviled constricting women's fashion, for "it has murdered more women, caused more misery, more crime, and more degeneracy than all the wars in human history" (5). At Physical Culture City, women could wear shorts, and sometimes ventured offsite in bathing costumes. In neighboring Helmetta, two "girl bathers" fled before anyone saw the "dangerous sight," causing such an uproar that authorities contemplated reviving a colonial statute mandating the stocks for "indecorous dress" ("Turns Back Girl Bathers"). Quickly and ironically, given MacFadden's strict prohibitions on meat, drink, and other vices that would bring about "the moral undoing of man or woman," the 
outpost gained a reputation as a haven for nudists and sexual deviants, suggesting how subversive a commitment to a life centered around exercise was perceived to be.

Still, being too fat could make one a laughingstock. In 1877, the New York Times mocked the "the fat man [who] is a mystery to himself, and his vague gropings after his correct solution are shown by his practice of associating himself with other fat men in clubs, and performing herculean feats of public overeating" ("Auxiliary Fat Men"). Exactly a century later, as the national fascination with jogging, yoga, and dance-exercise had solidly entrenched a slim, fit, ideal for men and women, the New York Times reminisced nostalgically about when "fat was in fashion" rather than a blight to be burned off at the health club. A "hilly and lustrous landscape of flesh" had long symbolized, in fat people, the "almost limitless possibilities of human mind and body" (Hollander).

Industrialization transformed these attitudes, expanding access to food, transportation, and labor-saving technologies, as well as sedentary desk jobs that became a middleclass norm. Gaining weight became all too easy in these years, and the social meaning of the fat body changed accordingly. By the 1920s, it signaled the failure to resist newly accessible pleasures. New Year's resolutions increasingly focused, as one 1922 Los Angeles Times headline declared, on "care of the body," which often meant weight loss. "Making a hog of yourself," or even "swallowing a mouthful" within two hours of waking, was as serious a betrayal of the Christmas spirit as greed or ostentation, this typical women's column sternly advised ("Care of the Body"). Still, "reducing" primarily meant food restriction rather than exercise. Indeed, young girls aiming to be more virtuous in the new year were to avoid "overindulgence in physical exercises and games," which might overtax their delicate constitutions ("Girl in School").

Though "thin was in," according to diet authority Lulu Hunt Peters, "reducing” wasn't only aesthetic. The stakes were moral and civic. Peters recommended establishing "Watch Your Weight Anti-Kaiser Clubs" to demonstrate the self-control to resist indulging while others, like those in interwar Germany, starved. When exercise resolutions slowly began to appear in the late 1920s, they were also directed primarily at fragile ladies as a strategy to stave off flabbiness and display class status ("Rendezvous of the Elite"). That "the flesh is weak" was assumed; what was not yet obvious was that within a few decades deliberately sculpting it with intense exercise would become a perennial expectation of women. (Peters 65).

The white, middle-class men who constituted the overwhelming majority of a workforce that undertook cerebral rather than physical labor faced new pressure to deliberately exert themselves, for dieting was considered an effeminate form of bodily mastery. On the one hand, sedentariness was a class marker that differentiated such men from the mere "breaker of stones" Sandow disdained. On the other, this "clerking class" who worked in offices found that the superiority afforded by their class came with a physical toll. Journalist Nikil Saval contrasted the finery such salaries supplied with the atrophied bodies it cloaked: "extravagant clothes but shrunken, unused bodies, backs cramped from poor posture, fingers callused by constant writing. When they were not thin, angular, and sallow, they were ruddy and soft: their paunches sagged onto their thighs" (9). While these male office workers would become an early, modest market for commercial gyms, they still viewed muscular bodies suspiciously, associated both with feminine physical cultivation and with the brutish masses "who literally do the heavy lifting" (Saval 14; see also Kimmel 203). 


\section{Education for Exercise}

30 By the end of the 1920s, fitness was on its way to becoming an aesthetic imperative, but it had to be learned. On college campuses, among the country's more privileged classes, the ideas and actions of deliberate recreational exercise took hold. "Sedentary habits predispose to every kind of outbreak, especially in youth," psychologist G. Stanley Hall warned in 1904, commending Amherst, Princeton, and Yale for advancing college gymnasiums from "feeble beginnings a few decades ago" to "the best safety-valve and aid to college discipline" (410-411). As early as the 1850s, students had organized "recreational" cricket, football, and baseball teams meant for those who might shy away from football matches, so brutal that in the mid-1880s, one Princeton student described regularly witnessing "savage blows that drew blood, and falls that seemed as if they must crack all the bones and drive the life from those who sustained them" (Abbott).

31 On that same campus in 1870 , the athletic director had attracted attention by scheduling a surprisingly popular one-time track meet open to all students. Formal intramural sports programs organized by the university and managed by a dedicated administrator were introduced at the University of Michigan and Ohio State in 1913, and the University of Texas in 1916, reflecting and encouraging a desire among college men to engage in sport for fun, and for what was becoming more widely acknowledged as the greater social and salutary benefits of exercise (National Intramural and Recreational Sports Association). That universities dedicated space and money to create these opportunities marked one step in entrenching fitness in American life. By 1939, Elmer D. Mitchell, Director of Intramural Sports and Professor of Physical Education at the University of Michigan, highlighted the urgency of pushing for such programs, which were still exceptional: "Today our schools graduate a man specialized for a particular vocation but they do not show him the way to health and happiness by keeping the play spirit alive" (Mitchell 10).

"Man" was the operative word, but Mitchell's boosterish book featured "activityminded" college women playing field hockey and swimming, and he endorsed these "healthful and recreative" outlets as appropriate for women. Barring "combative" sports like football, boxing, wrestling, and ice hockey that required "violent or prolonged effort," colleges offered group dance and other activities like fieldball, field hockey, archery, captain basketball, and even lighter forms of boxing "without any semblance of roughness" (Mitchell 70; Rouse 32). At Tulane University in 1915, "a leading society girl of Mississippi," who also happened to be reigning champion of a women's boxing contest, reassured critics who tried to cancel the competition that boxing was "a splendid form of exercise" that fostered "grace and self-reliance" (Rouse 31). Anxiety that white women lacked vitality and fortitude meant that on relatively cloistered college campuses, young women inspired by the "New Woman" ideal were often enthusiastically welcomed to participate, even by conservative administrations. In such programs, colleges sent the message that a full education, and personhood included strengthening the body, since the "natural" course of daily life would not, for the affluent, necessarily include much physical exertion. And healthy white men and women, after all, ensured the propagation of what they considered the superior elements of the human race. 
The role of educational institutions imparting this message that fitness is important beyond the realm of varsity athletics, and not only for men, is undeniable. But despite rising enrollments, these programs promoted this sensibility and attendant practices to a swath of society that almost entirely excluded immigrants, the formerly enslaved and their offspring, and many unable to afford college. Also, while the establishment of these programs signaled the rising social value of exercising for health, character, and beauty, college students still paid a supplemental fee to participate in the programs, indicating that recreational exercise was still understood more as a form of leisure than a fundamental aspect of selfhood or education.

34 It was in the less rarefied realms of public schools that the idea of regular exercise stood to get its strongest grip on society. As massive immigration transformed demographics, educators, reformers, and, more ambivalently, parents compelled attendance at public schools that were expected to teach children both academic skills and how to care for their bodies (Cantor 144-145). Exercise was crucial to this project. Public initiatives like the 1919 "Keeping Fit" and "Youth and Life" poster series recommended moderate exercise for girls and boys; a complementary series emphasizing fitness for agricultural labor and the bodily discipline of Frederick Douglass and Booker T. Washington targeted African Americans. By 1920, most states required physical education in public schools, and these classes represented both the liberatory and limiting sensibilities of a growing appreciation of exercise. On the one hand, some educators took up philosopher John Dewey's impassioned 1916 call "to develop the mind especially by exercise of the muscles of the body" and to abandon the damaging idea that "bodily activity [is] an intruder [...] an evil to be contended with" that "leads the pupil away from the lesson with which his 'mind' ought to be occupied" (Dewey). To Dewey, children's intellectual progress was impossible without engaging the body. His philosophy of progressive education influenced some educators to integrate not only physical play, but also gardening, construction, and community exploration into days otherwise defined by sitting at desks.

Simultaneously, broader concerns about which bodies were appropriate for which activities constrained physical education efforts. As historian Martha Verbrugge writes, many feared that building muscular strength and competitive spirit would make girls more masculine in appearance and attitude (Verbrugge, 2012 38). Advocates for girls' physical education often encountered popular beliefs that girls were ill-suited for running, weightlifting, or vigorous calisthenics that would cultivate excessive individualism and bulky muscles, and compromise their fertility. These advocates often found that group dance-which became a staple in public schools and on college campuses-was an acceptable activity.

Transatlantica, 2 | 2020 
Figure 3: Female students exercising at Western High School, Washington, DC, 1899. Library of Congress. www.loc.gov/pictures/item/2001699134. Accessed 15 February 2021.

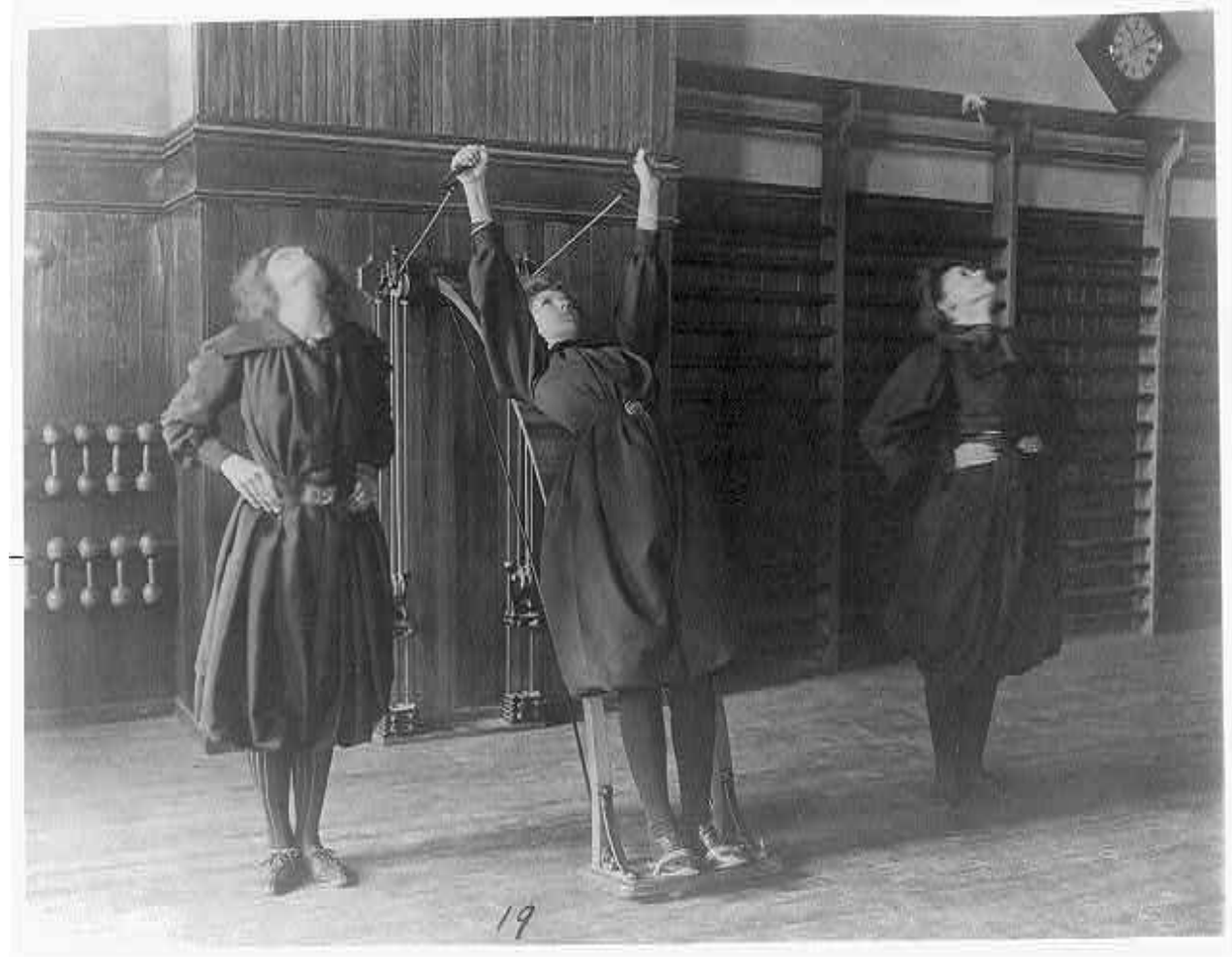

To a conservative medical establishment that believed girls and women were intrinsically weak-suffering "enfeeblement, lack of luster, debility, squeamishness about food, lack of interest in life, languid confidence, lack of incentive, and clammy hands"-activities such as "romping, ball, beanbags, battledore, hoops, running, golf, tennis, bicycling, self-bathing in cold-water, [and] deep breathing exercises once or twice a day" were thought conducive to preparing white, middle-class girls for motherhood and modern life (Hall 589). Hall wrote that a better solution than "sedulously reduc[ing]" the competitive element of sports, "dancing of many forms should be the most prominent of indoor exercises [...] as dance cadences the soul; the stately minuet gives poise; the figure dances train the mind" (638). Importantly, however, this medical opinion advanced by Hall and his colleague J. Madison Taylor hardly positioned exercise as of a piece with developing girls' autonomy and selfactualization. By contrast, they recommended to schools now serving as many girls as boys, often under the tutelage of women teachers, that "the development of ideal lawntennis girls would be a better goal for modern institutions than scholars made at such a cost" (581).

African American and immigrant children experienced physical education primarily as a form of discipline for bodies understood as inherently unruly. Whereas Hall expressly recommended intense, even "savage" physical activity as "a necessary ingredient of everything which captivates a boy's soul" to counteract the "gentle, give-and-take style" of doting mothers, teachers, and emasculated fathers, he understood white boys as the victims of the "social instincts of girls [...] in danger of too wide irradiation" $(428,431,523)$. Fears of feminization and "race suicide" were closely enmeshed. Hall reminisced about a time when urban classrooms and church groups were unadulterated by "girly" influences, and when white middle-class youths' "racial 
forbears [...] were rollicking, fighting, hunting, courting, as they roved with wild freedom on a quest for adventure" (428). Especially powerful during World War I, when public messaging about fitness for citizenship in general and military service in particular proliferated, physical education enjoyed status as a relatively high public priority, albeit with vastly unequal aims and often reflecting the underlying racist and sexist ideologies shaping society at large.

If the whistles and drills of school gymnasiums seemed a world away from the onstage whimsy of circus strongmen, both promoted versions of the "strenuous life," President Theodore Roosevelt's vision of rugged, vigorous pursuits ever easier to idealize in an urbanizing nation. Indeed, Sandwina's child, known in the press as "superbaby"-he weighed fifty pounds at age two and became a professional boxer-was named after Roosevelt, who personally commended the positive example she set by exercising for health and hardiness. Sandow too promoted strength training for all, writing in 1897 that babies should have "light wooden dumbbells as playthings," and including exercises for men, women, children, and athletes of two skill levels-"Athletes"' and "Athletes' Extra Heavy". Almost simultaneously, Sandow's promoter MacFadden marketed his own "Exerciser," bands that could be attached to a door frame, as appropriate for "strongmen," "ladies," and a "child." Though these circus performers primarily paraded onstage as individuals, they parlayed their fame to encourage exercise for everyone as imperative to ennobling self and society, if not a truly democratic one.

\section{Promoting the Fit Body}

A majority of states spread this ethos by requiring physical education by the 1920 s, but the Depression scaled back many programs. The New Deal, however, promoted the importance of physical fitness for the masses in new ways, specifically for men. Franklin Delano Roosevelt's legacy is expanding the federal infrastructure, but these initiatives also promoted bodily fitness and means to achieve it. The federal Civilian Conservation Corps, as historian Rachel Louise Moran chronicles, put three million unmarried young men to work on land conservation from 1933 to 1942, and was particularly powerful in this regard. Enjoying one hundred times the funding of the Children's Bureau that focused on schools and other youth outreach, the CCC's $\$ 300$ million budget allowed it to promote the idea that an ideal, adult male body was muscular and capable of physically challenging labor (46).

This fit male physique was strikingly different from many of the most visible bodies at the time: the impoverished poor weakened by the privation of the Depression, veterans disabled in World War I, the effete, slender office workers with outsized brains and underdeveloped muscles, and the corpulent capitalist whose girth that had so recently signaled enviable luxury now projected decadence. Importantly, it was also white. The CCC was briefly racially integrated, but by 1935 southern Democrats ensured that the 200,000 African Americans who served worked in segregated camps. Similarly, an Indian Division employed 85,000 Native Americans on reservation development projects, but minorities were absent from leadership and the CCC's extensive publicity, affirming the whiteness of what scholars later styled "musculinity" (Wagner). of the thousands of federally funded sites that promoted democratic participation in 
fitness and recreation as the economy regained its footing. By the end of 1930s, however, the United States had largely settled into what Moran calls an "advisory" role in promoting bodily health: encouraging Americans to exercise, but never investing in the expensive infrastructure, education, and enforcement mechanisms necessary to compel action (4). Institutions that could afford it, like colleges, mixed institutional funding with student fees to consolidate offerings in recreation and fitness. As the Depression stripped back public school funding, by 1933, thousands of programs were up and running on college campuses, entrenched since World War I in a new department in normal schools: physical education (National Intramural and Recreational Sports Association).

The vivid, brightly colored promotional posters commissioned by unemployed artists who rendered toned men hard at work to right the American economy and keep their male dignity intact spread this ideal even further, hung in public buildings like post offices and train stations. Yet a controversy over one mural commissioned by another federal initiative, the Public Works Administration (PWA), revealed that the New Deal reimagination of physical exertion as associated with conventionally masculine values like labor and discipline was hardly complete. In 1934, artist Paul Cadmus completed "Fleet's In," a PWA-funded mural depicting strapping men carousing with women in tight-fitting, attention-grabbing outfits. Most outrageously, the men were "too friendly with each other," one Navy Admiral charged, demanding that the offending tableau be removed from the Corcoran Gallery of Art (Armengol 65). Cadmus, in implying the homoerotic charge of muscular male bodies, struck a nerve in a society grappling with just how to define gender and, secondarily, its relationship to exercise.

Notably, a painting Cadmus completed for the Treasury Relief Art Project was also deemed "unsuitable" for display in a federal building. Titled "Golf," it showed a young, muscular caddy laboring for a group of paunchy old men in expensive clothes chomping on cigars and leering at their employee (Armengol 65). Cadmus promoted what was becoming a dominant set of assumptions about male bodies: muscles that showed work were more attractive than flabbiness that conveyed laziness. Yet his suggestion that these newly attractive male bodies might attract male attention, and that the moral failings of the rich might be sexual was too much for the public to bear, or at least for the government to fund. As art historian Josep Armengol writes, "even if the (official) discourse of the Roosevelt administration asked the publicly hired artists to record, paint, and write about what they saw, it is clear now that they always expected some things to be kept hidden, some red lines not to be trespassed" (66).

If physical education, public health initiatives, and popular culture introduced and established the attitudes that uphold the modern fit nation, it was a new market that exploited this nascent appetite in the early twentieth century and expanded it, even during the Depression. Charles Atlas invested the winnings from his two consecutive "World's Most Perfectly Developed Man" titles in a business selling fitness devices to those he assumed aspired to a frame like his. The "Dynamic Tension" devices Atlas sold with his marketing partner, Charles Roman, built strength by "pitting one muscle against another," a technique that occurred to him as a scrawny boy observing a lion loping powerfully through the newly opened Bronx Zoo. But the business foundered, ironically, until the same year the economy crashed.

Atlas promoted the relatively new idea that a strong body was sufficiently desirable to merit investing time and money in cultivating. Targeting young men, Roman and Atlas 
ran comic-strip ads starring a "97-pound weakling" whose silhouette was embarrassingly similar to that of his slender date, and who was powerless to defend himself against a brawnier guy with designs on her. The message, though its claims were untested and prompted lawsuits, enticed young men unsure of their ability to accomplish the traditional marker of masculine success: protecting a vulnerable female companion ("Fireworks Group"). Moreover, with no equipment to manufacture or ship, the method was an affordable indulgence. The promise Atlas made in bold print-"I Can Make This New Man of You"-began with reading a free book, and proved so appealing that by the 1940s two dozen women staffed his Manhattan headquarters, fielding inquiries from as far as England and India.

Mail-order businesses, which often promised that the results of physical exercise could be attained in just minutes daily, and at home, proved more lucrative than brick-andmortar facilities. Physical Culture City had foundered in a few years, due not only to outside opposition, but to the relative few keen to immerse themselves in physical culture. Demanding a less extreme commitment, even gymnasiums struggled to survive in a culture in which spending time and money to exercise, and in an unfamiliar social group, was unheard of. In the first three decades of the twentieth century, MacFadden, Atlas, and another bodybuilder named Jack Lalanne all opened gyms and struggled to find a clientele, investors, and infrastructure (Latham). When Lalanne opened a gym in Oakland in 1936, he had to hire a blacksmith to custom-build equipment. More effective were the media and mail-order regimes that these men-and others, like Pennsylvania's Bob Hoffman, who wrangled with McFadden over a competing systemused to make a profit, thereby spreading a nascent fitness culture to a diffuse public.

The men who participated in this emergent subculture in the first half of the twentieth century were often considered unintelligent or effete for tending so attentively to their bodies. The connection of gyms and deviance wasn't only abstract. In an era when homosexuality was being excluded from the public sphere (Chauncey 331), physique culture could provide cover, and solace, for men seeking such community. Magazines like Physical Culture, with their near-naked models inspired by homosocial ancient Greece, arguably exaggerated traditional ideas about gender because these associations were so strong (Johnson). MacFadden reviled those who associated his magazine with homosexuality and celebrated beating up gay men: "nastiness exists in the minds of those who view it, and those who possess such vulgar minds are the enemies of everything clean, wholesome, and elevating" (quoted by Chauncey 116). Chauncey argues that MacFadden feared being perceived as harboring "the depraved sexual desires of a degenerate" (116). Sandow, widely acknowledged as the ambassador for bodybuilding to the United States, reflected Victorian social norms in his discretion about sex, but the press reported on his "great and inseparable friend" Martin Sieveking, with whom he "took up housekeeping" on West $38^{\text {th }}$ Street in New York, a fact that leads some contemporary scholars to identify him as bisexual (Alvarez 43).

Much as Sandwina had performed her normalcy by wearing frills and cooking for her children, Atlas and his fellow male fitness entrepreneurs presented an exaggerated heterosexuality. Notably, the 97-pound weakling clarifies that his rationale for bulking up is to impress his girlfriend and to punch out, rather than cozy up to, the muscular male aggressor. In ads targeting men, any indication that the reader might be purchasing a "beauty product" was buried beneath layers of language promising strength and virility. At the bottom of Atlas's early print ads, for example, he 
enumerated aesthetic outcomes in fine print: "banishing such ailments as [...] pimples, skin blotches, and the others that do you out of the good things and good times in life" (Charles Atlas Advertisement). Products to fix these problems, already the mainstay of a brisk women's skincare business, were only reluctantly marketed to men thought to find such concerns embarrassingly womanly.

These men labored against such assumptions and sought to connect cultivating the body with work that was at once refined and masculine. Brawn suggested a workingclass brutishness, but the bodies clerical work created were unattractively weak. Thus a new physique, deliberately toned by products pitched at white-collar workers, emerged. Simon Kehoe, a Briton who imported "Indian Clubs" lamented the paucity of gymnasiums, and that those that existed were rarely equipped for proper use of the clubs that the British army had first seen among Indians during the colonial occupation (10). Kehoe touted the popularity of the clubs among professionals: "Merchants, bankers, clerks, and those engaged in daily business pursuits, who need some available means of exercise to counteract the ills arising from their sedentary occupations, are many of them becoming experts with the Clubs, and reaping everlasting benefits" (Kehoe 9).

Working hard at their desks and their physiques, these men were changing the urban landscape. In stark contrast to "the shoals of painted, perfumed, Kohl-eyed lisping, mincing youths that at night swarm Broadway in the Tenderloin section, or haunt the parks on Fifth Avenue, ogling every man that passes," as MacFadden had in 1904 denounced the gay men frequenting these areas (quoted in Chauncey 179), Kehoe wrote: "Note in the crowded thoroughfare of Broadway now and then an occasional passer-by, with well-knit and shapely form, firm and elastic step, broad-chested and full-blooded, and you may mark him down as one of Kehoe's converts. The names of these well-known New Yorkers are too numerous for mention here" (9).

In some way, fitness was an easier sell to women, because enthusiasts framed fitness as a way to achieve beauty, understood as a conventionally feminine aspiration. That clear skin and a small waist were desirable for health and beauty was first explicitly articulated by antebellum reformer Catherine Beecher, who detested how sartorial presentation had become "the ruling thought" of many young girls' lives, crippling their self-regard, spirit, and sometimes literally their bodies. The "protracted agonies" of deformed bones, palpitations, and a constant nervous, anxious state, Beecher pleaded with a presumed white reader, were more damaging than "horrible torments inflicted by savage Indians or cruel inquisitors" $(243,250)$. A redefinition of beauty was needed because "the war of fashion," waged with whalebone stays and corset-strings, was disfiguring the very bodies it was meant to beautify. Physical attractiveness was paramount, Beecher explained, but it was rooted in teaching girls to "realize the skill and beauty of construction shown in her earthly frame, the more she will feel the obligation to protect it from injury and abuse" through pursuits like moderate exercise, healthy food, useful work, and sensible dress-not by worshipping the false idol of fashion (273).

Beecher was not alone in arguing for a redefinition of beauty that elevated bodies that showed the effects of exercise rather than dress, but this line of thinking was not always liberatory. Nearly thirty years later, MacFadden's perspective clarified the limits of his campaign against the "grotesque deformity" of the bone-crushing corset. According to MacFadden, "woman's universal desire" for a small waist should be 
challenged because corsets "threatened to deteriorate the race." In his 1901 text on "superb womanhood," MacFadden quotes Prof. O.S. Fowler at length:

If it were merely a female folly, or its ravages were confined to its perpetrators, it might be passed unrebuked; but it strikes a deadly blow at the very life of the race. By girding in the lungs, stomach, heart, diaphragm, etc., it cripples every one of the life-manufacturing functions, impairs circulation, impedes muscular action, and lays siege to the child-bearing citadel itself. By the value of abundance of maternal vitality, air, exercise, and digestion, is this practice murderous to both. It often destroys germinal life before birth, or soon after, by most effectually cramping, inflaming, and weakening the vital apparatus, and stopping the flow of life at its fountain-head. It takes the lives of tens of thousands before they marry, and so effectually weakens and diseases as ultimately to cause the deaths of millions more. [...] If this murderous practice continues another generation it will bury all the middle and upper class of women and children, and leave propagation to the coarse-grained but healthy lower. Most alarmingly has it already deteriorated our race in physical strength, power of constitution, energy, and talents. Reader, how many of YOUR weaknesses, pains, headaches, nervous affections, internal difficulties, and wretched feelings were caused by your own or mother's corsetstrings? Such mothers deserve execration. (80-81)

Slowly but surely, even those with deeply conservative ideas about gender entertained the notion that exercise could entrench rather than erode these roles. Sure enough, the most powerful growth in women's fitness in the early twentieth century came not from federal investment, which always focused on male potential soldiers, or from athletics that were still regarded with suspicion by many Americans. Tending to the body for beauty became a powerful way that a nascent industry sold "figure control" and "slenderizing" at first through "passive exercise" to women who wouldn't go for sports, self-defense, or more intense activities gaining popularity. The sensibility shift was widespread, and often grassroots. Black women, historian Ava Purkiss writes, established "rolling clubs" to "literally roll off excess weight," as the Savannah Tribune reported in 1910. The fourteen Oklahoma women who gathered weekly "in a desperate attempt to slim down" were convened by "one of the stoutest creatures west of the Mississippi." Though most members were relatively affluent "society matrons and buds," the club that put "everything fat and feminine on the roll" was shaped by two simultaneous pressures: the popularity of a slim, "hipless" look dictated by the overwhelmingly white aesthetic of fashion magazines and especially intense pressure for black women to resist stereotypes casting them as obese or masculine" (27).

The beauty industry quickly fulfilled this appetite for exercise to enhance appearance with offerings such as "slenderizing spas" that employed gentle exercise to help women "reduce" in "luxurious comfort" without disrupting any notions of conventional femininity, and certainly without compelling women to enter gymnasiums. Luxuriously appointed salons established by beauty entrepreneurs like Helena Rubinstein and Elizabeth Arden became popular destinations for those seeking expert intervention on their mission for "figure control." Though activities in these spas could barely be described as exercise in the sweaty, contemporary sense, they introduced the idea that women collectively working their bodies could enhance rather than endanger femininity.

At the New York City salon that Rubinstein established as the "Maison de Beauté Valaze" in 1915, the year she and her Jewish family left France, she cautiously navigated notions of how a woman should act and in which spaces it was appropriate to congregate. The salon's décor of “deep blue walls, rose baseboards, [...] green velvet 
carpets, [...] red tables," and "embroidered pillows" was "reassuringly domestic, somewhat upper crust, and above all respectable," historian Marie J. Clifford wrote of how Vogue portrayed the space to readers who might have been intimidated to enter, much less exercise, somewhere that did not resemble familiar domestic spaces (Clifford 86). Notably, these luxurious trappings also conferred bourgeois legitimacy on Rubinstein, whose Jewishness often chilled her reception in New York City society.

Elizabeth Arden also decorated her modern Fifth Avenue salon with smart decor that recalled her clientele's chic apartments (Clifford). A 1930 Fortune article described the exercise studio as appointed with luxuriant satin drapes and chairs upholstered with "interlocking pink and green" fabric reminiscent of Georgia O'Keeffe's work, which as of 1936 would literally adorn the walls of the "Gymnasium Moderne" (Clifford 93). Arden and Rubinstein charted new ground in welcoming Junior League socialites, stenographers, and secretaries alike-"women who could afford it," as one British news segment characterized them-to spend time and money on exercise along with the more culturally acceptable bodily work of skin and hair care ("Battle of the Bulges").

The reducing-machine craze went national. "Figure control rooms" and "silhouette salons" loosely inspired by Arden and Rubinstein's palaces popped up in towns, suburbs, and cities. Engineered to "soothe the nerves and control the curves," one 1930s Chicago beauty salon described its two offerings, one "thorough and scientific" for "the fats" carrying "excess poundage" and another circulation regime for "the tired business woman" in less dire need of "curve control," the relatively affordable salons quickly became popular (Nangle D5). Some featured installment plans for as little as $\$ 1.00$ per fifteen-minute visit-during which one could lose "AS MUCH AS THREE POUNDS!", as one national chain advertised in 1956 ("Inches Off!"). By 1957, one city of 750,000 had 22 women-only reducing firms charging between two and ten dollars for "who-knows-how-many treatments," Kiplinger's Personal Finance reported skeptically ("Those Reducing Salons" 13). Usually located adjacent to beauty salons rather than in still-suspicious gyms, slenderizing outfits gingerly acculturated women, who often kept their high heels on during sessions, to the idea of exercise.

57 A veneer of scientific legitimacy was key to selling these services. These entrepreneurs consulted with physicians and staffed up with "technicians" to operate machinery ranging from electric massagers that primarily shook "the right spots" to "dissolve fatty tissues" and "eliminate inches" to the full-body "relax-and-reduce" massage popular in the late 1940s and 1950s. "We hope we haven't made all this sound frivolous," one profile of a Chicago silhouette salon clarified, "it's serious beauty work." This legitimacy, the journalist argued, had to do with the transactional nature of the experience-"the individual needs of the client are carefully considered"-and its scientific basis: "some courses are given with the cooperation of a physician" (Nangle D5). Men were putting their bodies on the line at war, a British news segment reported, but reminded women they still had crucial "Battles of the Bulge" to wage on their fleshy bodies ("Battle of the Bulges").

The effectiveness of these high-tech treatments, however, was dubious. These "cagelike platforms housing a contraption of coils and metal poles" were billed as so innovative they could increase women's vitality, strength, and beauty without requiring much movement or inducing an unladylike sweat ("Those Reducing Salons" 13). "Reducing is hard work? NONSENSE!", advertised one mid-1940s machine (Elizabeth Arden Advertisement). Safety was also an issue: in 1949, the Los Angeles Times 
reported that a woman trapped in a malfunctioning machine suffered "bone bruises" before an emergency police rescue ("Reducing Machine Entraps Girl"). Yet women, not faulty machinery and false advertising, were often blamed for patronizing these businesses. One journalist took aim at those willfully denying "real problems of overweight," like a "dumpy, middle-aged, old lady who walked into a salon one day recently" and despite carrying "some 25 pounds of dangerous overweight by medical standards," announced, "just get off this roll of fat-right here-and I'll be satisfied" (“Those Reducing Salons" 13).

Figure 4: Elizabeth Arden Reducing Salon advertisement, 1944. John W. Hartman Center for Sales, Advertising, and Marketing History at Duke University. https://repository.duke.edu/dc/adaccess/ BH1367. Accessed 15 February 2021.

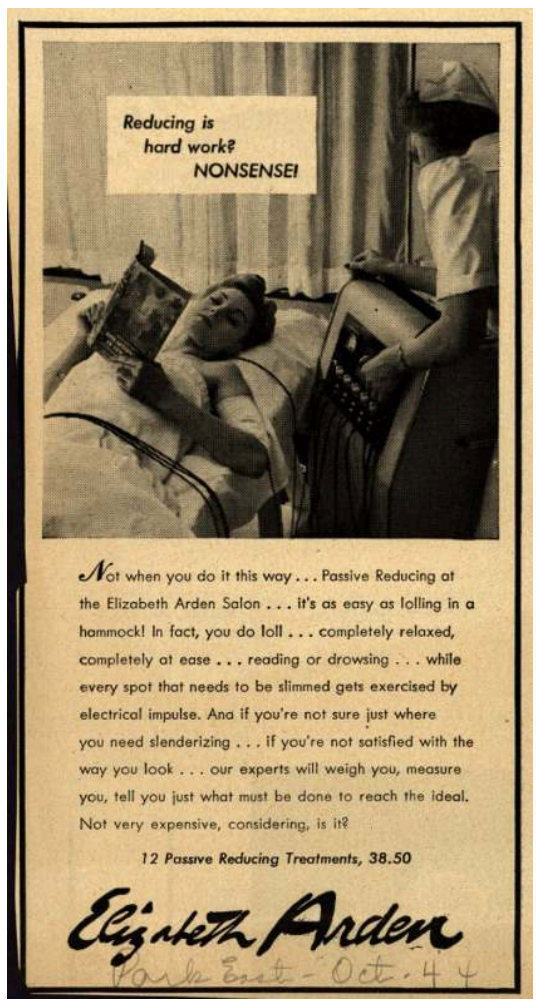

59 At-home regimes promised easier access to achieve these same effects. Women's magazines amplified the idea that making time for exercise, however gentle, was something between a right and a requirement of ladyhood. "Exercise for Beauty's Sake," instructed a curlicued headline, stretched across a two-page photo spread in Vogue in 1926. Women who found themselves "fair, forty, and fat," the piece imparted, might be intimidated by the lithe women photographed in backbends and twists, but this was no excuse "not to take action against" the "cumbersome pounds" that stood between so many women and "grace of body and courage" ("Exercise for Beauty's Sake"). Rare were products marketed to both men and women, like a 1939 booklet of "West Point Exercises" used at the United States Military Academy and incongruously marketed as "a simple, inexpensive way to achieve a graceful figure" (Advertisement). Billed in 1956 as "the normal, healthy way to pull in inches," the Relax-A-Cizer was marketed to a "busy woman" with no time for gym or salon but with a desire for "real exercise," though not to be confused with "bicycles, massage tables, heat, or massage," all of which involved sweat. On the contrary, "you exert no effort" with this miracle 
device: "you REST at home. No effort is required. You use it while you read, rest, watch television... even while you sleep!" ("Woman Reducing Waist").

As ever, women who went in for slenderizing walked a fine line. If prioritizing beauty guarded against appearing unfeminine, frivolity and excessive vanity were also unseemly. Helen McKenna had lived her life "a hopeless prisoner in a ton of flesh" and had been counseled away from reducing by friends who warned her of "the horrible things that happen to people who try to reduce," foolishly wasting money on faddish treatments. Indeed, McKenna had subjected herself to "terrific workouts" of "calisthenics, diet, sports, and massage," dropping as much as thirty pounds over the summer, but then gaining it all back, "with a little more for good measure." Dispirited by this cycle, in September 1937, McKenna walked tentatively into a ballet class, anticipating the humiliation of being cast out for being too "fat and awkward." She wasn't. Before long, McKenna was no more able to quit than "to cut her own arm off" and lost seventy pounds mastering the Pavlova gavotte, the Mexican Hat Dance, and a Chopin waltz. Now wearing "bright, luscious colors" and "less old-maidey clothes," McKenna won her "battle over fat," a Dance magazine feature argued, because she eschewed superficial reducing for an elevated, "happy, artistic" pursuit (McKenna 25-27).

61 By the 1940s, some women passionate about sports, self-defense, and developing their own strength trained rigorously, regardless of these passions being perceived by many as "mannish" (Cahn 164). But an enduring cultural expectation that women were constitutionally weak kept many from the gym, or at least constrained the range of exercises considered appropriate. Ironically, men steered clear of the gym for a complementary but contradictory reason: spending so much time on their bodies was thought to diminish their virility with the effete pursuit of beauty or the blandishments of other men. A joke in one 1956 profile of a Washington, DC Slenderella suggests as much: in response to men's curiosity about the mysterious spaces to which their wives dispatched for treatments, the company might be opening men's salons, "which they will definitely not call slender-fella!" (McLendon).

The growing interest in fitness, paradoxically, both upheld and began to erode these assumptions about gender. Muscular Christianity and military readiness for two world wars invigorated old ideas about male strength that could be newly displayed in sculpted physiques like those that had existed mostly as onstage spectacles when Sandow performed at the World's Fair. Similarly, group dance and stretching classes emphasizing grace and beauty, and the clunky reducing gadgets that assumed female frailty could in important ways entrench the idea that women were made to be passive and pretty. Yet the mere act of embarking on these body projects-whether joining a gymnasium to shape your muscles with other men or making a habit of meeting up with other "business girls" in women's-only studios-introduced thousands of both sexes to the idea that deliberate cultivation of the body was a meaningful pursuit, marking a departure from the idea that working out belonged on the circus stage (Nangle).

\section{Participating in the "Fit Nation"}

More than a half-century after the solitary Sandow flexed at the World's Fair, a different scene transpired on another stage across the country. In the 1940s and 1950s, 
Santa Monica locals and tourists alike gathered on "Muscle Beach" to watch suntanned strength enthusiasts like Jack Lalanne and Abbye "Pudgy" Stockton-crowned "Miss Physical Culture Venus" by MacFadden-throw each other high against the bright sky or hoist hundred-pound barbells overhead. The men were clad in tight-fitting trunks and Stockton donned a two-piece she had fashioned from a ripped brassiere to allow greater range of motion. These aficionados had begun gathering at the New Deal era playground, envisioned by the WPA and local authorities as a space to hold activities for impoverished children, to practice acrobatics, lift weights, and play volleyball and Ping Pong (Harvey). First spreading tarps right on the sand, the community drew ever larger crowds with their physical feats (Rose).

Children continued to show up at this playground for adults. A typical Fourth of July celebration in the mid-1940s involved an afternoon of acrobats stacked four or five high, women dramatically tearing apart phone books, or mock-wrestling men, all, even young children, apparently effortlessly lifting weights (Rose 12). Muscle Beach was liberating exercise from deliberately discrete spaces-dank, subterranean gyms, slenderizing spas in the back rooms of beauty salons, and even the private living rooms where timid exercisers experimented with their latest mail-order apparatus or routine -and into the bright sunlight. So close to Hollywood, plenty of Muscle Beach regulars were aspiring actors and casting directors often scouted the sandy space for stunt doubles or, occasionally, as in Steve Reeves of Hercules fame, as a lead role that gave these sculpted bodies-and exercise culture-a grander stage than any playground or live performance to promote fitness as a way of life.

In some ways, what the bodies on that Santa Monica stage could do felt as otherworldly as had Sandow and his contemporaries. Historians Jan and Terry Todd remarked to Reeves that "people must have seen you walking down the beach and thought you were from a different planet" (Todd and Todd). But something was changing and a 1949 photograph of the weekend scene at Muscle Beach, by Max Yavno, captures this shift. At least eight muscular performers hang on bars, showing off an isometric contraction that would have impressed Atlas, while others toss each other in the air in adagio, and execute backbends and tumbles, glistening muscles showing their effort. Yet far more people milled about the low stage, squinting to see the action and allowing their children to be hoisted to the bars in demonstrations. Many dressed as revealingly as the performers, making the difference between their bodies difficult to ignore.

The space between those on the stage and the spectators with sand between their toes was narrowing. Getting gorgeous, healthy, and strong in the sunshine fit seamlessly with the image of an ever more widely marketed California culture. By the 1940s, Muscle Beach and the fit bodies with which it was associated not only drew crowds of tourists and aspiring hardbodies, but was entrenched in popular culture, popping up on television as a go-to laugh line, "like Brooklyn," for "wise-cracking comedians of stage, screen, TV, and gossip columns from Coast to Coast" (Devienne 336). Just off to the right of the stage, a sign that advertised "Physical Services" in "Conditioning and Development" offered an opportunity to bridge that gap, reminding the spectators that if they invested time, money, and sweat, they could become as strong as those before them, close enough to touch.

Mid-century Muscle Beach would not exist without the strength promoters who posed onstage and in magazines, but it also represented a newly porous relationship between performer and public. Sometimes quite literally: in the late 1950s Muscle Beach star Bill 
Pearl would don gladiator sandals and a wig to perform Sandow's classic stunts, showing both a debt to the early strongmen and highlighting how far they had come. No longer primarily performers, midcentury fitness enthusiasts embodied, and sold, an ideal to which many more Americans began to aspire. The audiences that thronged Muscle Beach were arguably the last who would witness exercise primarily as spectacle, blissfully free of that familiar twinge of guilt upon seeing someone else sweat: I should really work out today. The fit nation as we now know it was in formation.

\section{BIBLIOGRAPHY}

ABBOTT, Karen. “Score One for Roosevelt." Smithsonian Magazine, 20 September 2011. smithsonianmag.com/history/score-one-for-roosevelt-83762245.

Accessed 8 December 2020.

Advertisement, “West Point Exercises” booklet. Chicago Daily Tribune, 25 August 1939.

ALVAREZ, Erick. Muscle Boys: Gay Gym Culture. New York: Routledge, 2010.

“Apotheosis of Corpulence (The)." The New York Times, 27 June 1870.

ARMENGOL, Josep. "Gendering the Great Depression: Rethinking the Male Body in 1930s American culture and literature." Journal of Gender Studies, vol. 23, no. 1, 2012, p. 59-68.

“Auxiliary Fat Men.” The New York Times, 24 February 1877.

BASU, Tanya. “The Forgotten History of Fat Men's Clubs.” National Public Radio, 10 March 2016.

"Battle of the Bulges." 13 January 1941. British Pathé online archive.

BEDERMAN, Gail. Manliness and Civilization: A Cultural History of Gender and Race in the United States, 1880-1917. Chicago: University of Chicago Press, 1995.

BEECHER, Catherine. Miss Beecher's Housekeeper and Healthkeeper. New York: Harper \& Brothers, 1873.

BLACK, Jonathan. “Charles Atlas: Muscle Man.” Smithsonian Magazine, August 2009. smithsonianmag.com/history/charles-atlas-muscle-man-34626921.

Accessed 8 December 2002.

CAHN, Susan. Coming on Strong: Gender and Sexuality in Twentieth-Century Women's Sport. Cambridge, MA: Harvard University Press, 1995.

CANTOR, Milton. "Education and the Nineteenth Century Working Class." Work, Recreation, and Culture: Essays in American Labor History. Eds. Martin H. Blatt and Martha K. Norkunas. New York: Routledge, 1996, p. 144-145.

"Care of the Body." The Los Angeles Times, 24 December 1922.

CAREW, Kate. “Barnum and Bailey's ‘Strong Woman' Tells Kate Carew-This Young Goddess of the Tan Bark, Who Tosses Her Husband About as She Would a Feather, Explains How She Came By Her Strength." New York American, 16 April 1911, p. 2-M. 
CHAPMAN, David L., and Patricia VERTINSKY, Venus with Biceps: A Pictorial History of Muscular Women. Vancouver: Arsenal Pulp Press, 2011.

Charles Atlas Advertisement. 1930. Online archive at charlesatlas.com/classicads.html. Accessed 7 February 2019.

CHAUNCEY, George. Gay New York: Gender, Urban Culture, and the Making of the Gay Male World, 1890-1940. New York: Basic Books, 1994.

CHILDRESS, Micah. "Life beyond the Big Top: African American and Female Circusfolk, 1860-1920." The Journal of the Gilded Age and Progressive Era, vol. 15, no. 2, p. 176-196.

CLIFFORD, Marie J. “Helena Rubinstein's Beauty Salons, Fashion, and Modernist Display.” Winterthur Portfolio, vol. 38, no. 2/3, 2003, p. 83-108.

“Comstockery vs. MacFaddenism," The New York Times, 7 October 1905.

DEVIENNE, Elsa. "The Life, Death, and Rebirth of Muscle Beach: Reassessing the Muscular Physique in Postwar America, 1940s-1980s." Southern California Quarterly, vol. 100, no. 3, 2018, p. 324-367.

DEWEY, John. Democracy and Education. 1916. Project Gutenberg Web Edition. gutenberg.org/files/852/852-h/852-h.htm.

Accessed 4 January 2019.

Elizabeth Arden Advertisement. 1944. Duke University Digital Collections. repository.duke.edu/dc/adaccess/BH1367.

Accessed 15 February 2021.

"Enlist Suffragists for a Circus Holiday: Baby Giraffe Named 'Miss Suffrage' at a 'Votes for Women' Rally." The New York Times, 1 April 1912.

“Exercise for Beauty's Sake.” Vogue, 13 November 1926.

FARRELL, Amy Erdman. Fat Shame: Stigma and the Fat Body in American Culture. New York: New York University Press, 2011.

"Fireworks Group Is Cited on Pricing." The New York Times, 28 January 1938.

“Girl in School (The)." The Dayton Herald, 12 May 1911, p. 13.

GREEN, Harvey. Fit for America: Health, Fitness, Sport, and American Society. Baltimore: Johns Hopkins University Press, 1986.

GRIFFITH, R. Marie. Born Again Bodies: Flesh and Spirit in American Christianity. Berkeley: University of California Press, 2004.

HALL, G. Stanley. Adolescence: Its Psychology and Its Relations to Physiology, Anthropology, Sociology, Sex, Crime, Religion, and Education. New York: Appleton, 1904.

archive.org/details/adolescenceitsp01hallgoog.

Accessed 8 December 2020.

HARVEY, Steve. "Mussel or Muscle? Whatever You Call It, It's a Beach That's Not Forgotten By Many Devotees." The Los Angeles Times, 30 March 1986.

HOLLANDER, Anne. “When Fat Was in Fashion.” The New York Times, 23 October 1977.

HULLS, Tessa. "The Great Sandwina, Circus Strongwoman and Restaurateur." Atlas Obscura, 26 December 2017. 
atlasobscura.com/articles/the-great-sandwina.

Accessed 8 December 2020.

"Inches Off!" Advertisement for Alvin Roy Slenderizing Salons. St.-Louis Globe Democrat, 24 September 1956.

JOHNSON, David K. "Physique Pioneers: The Politics of 1960s Gay Consumer Culture." Journal of Social History, vol. 43, no. 4, 2010, p. 867-892.

JONES, Martha. Vanguard: How Black Women Broke Barriers, Won the Vote, and Insisted on Equality for All. New York: Basic Books, 2020.

KEHOE, Simon D. The Indian Club Exercise: With Explanatory Figures and Positions. New York: American News, 1866.

KIMMEL, Michael. Manhood in America: A Cultural History. 1996. New York: Oxford University Press, 2018.

LATHAM, Alan. "The History of a Habit: Jogging as a Palliative to Sedentariness in 1960s America." Cultural Geographies, vol. 22, no. 1, 2015, p. 103-126.

MANCHESTER, Herbert. Four Centuries of Sport in America, 1490-1890. 1931. Lyon: Derrydale Press, 1991.

MACFADDEN, Bernarr. The Power and Beauty of Superb Womanhood. New York: Physical Culture Publisher, 1901.

MARTYN, Marguerite. “The ‘Lady Hercules' Tells Marguerite Martyn.” St. Louis Post-Dispatch, 4 June 1911.

MCKENNA, Helen. “What Dancing Did for Me.” Dance magazine, November 1942, p. 25-27.

MCLENDON, Winzola. "Got a Weighty Problem? Then Take It Lying Down.” The Washington Post and Times-Herald, 22 August 1957.

MITCHELL, Elmer D. Intramural Sport. New York: A.S. Barnes, 1939. NIRSA Archive, Corvallis, OR. MORAN, Rachel Louise. Governing Bodies: American Politics and the Shaping of the Modern Physique. Philadelphia: University of Pennsylvania Press, 2018.

NANGLE, Eleanor. "Through the Looking Glass: Silhouette Treatments at a Local Salon Offer Perfect Contours." Chicago Daily Tribune, 7 June 1936, p. D5.

NATIONAL INTRAMURAL AND RECREATIONAL SPORTS ASSOCIATION. "Statement." NIRSA Archive, Corvallis, OR. NIRSA thesis, 1933 intramurals.

PETERS, Lulu Hunt. Diet and Health; With Key to the Calories. Chicago: Lanval Press, 1918.

PURKISS, Ava. “'Beauty Secrets: Fight Fat': Black Women's Aesthetics, Exercise, and Fat Stigma, 1900-1930s." Journal of Women's History, vol. 29, no. 2, 2017, p. 14-37.

“Reducing Machine Entraps Girl.” The Los Angeles Times, 2 October 1949.

“Rendezvous of the Elite (The)." The Los Angeles Sunday Times, 30 September 1923.

ROSE, Marla Matzer. Muscle Beach: Where the Best Bodies in the World Started a Fitness Revolution. Los Angeles: LA Weekly Books, 2001.

ROUSE, Wendy L. Her Own Hero: The Origins of the Women's Self-Defense Movement. New York: New York University Press, 2017.

SANDOW, Eugen. Strength and How to Obtain It. New York: Gale and Polden, 1897. 
SAVAL, Nikil. Cubed: The Secret History of the Workplace. New York: Doubleday, 2014.

“Those Reducing Salons: Do They Really Slim a Lady Down?” Kiplinger Personal Finance Magazine, March 1957, p. 13.

TODD, Jan. "Katie Sandwina and the Construction of Celebrity." Bandwagon, vol. 56, no. 2, 2012, p. 28-35.

TODD, Jan, and Terry TODD. “The Last Interview." Iron Game History: Journal of Physical Culture, vol. 6., no. 4., 2000, p. 1-14. LA84 Foundation Digital Archive.

“Turns Back Girl Bathers: Is Troubled By Folk Who Say They Hate Clothes." The New York Times, 27 August 1915.

Untitled. Beauty and Health, vol. 6, March 1903, p. 1-284.

VERBRUGGE, Martha. Able-Bodied Womanhood: Personal Health and Social Change in NineteenthCentury Boston. New York: Oxford University Press, 1998.

VERBRUGGE, Martha. Active Bodies: A History of Women's Physical Education in Twentieth-Century America. New York: Oxford University Press, 2012.

VERTINSKY, Patricia A. The Eternally Wounded Woman: Women, Doctors, and Exercise in the Late Nineteenth Century. Chicago: University of Illinois Press, 1994.

WAGNER, Philip E. Musculinity: A Critical Visual Investigation of Male Body Culture. PhD dissertation, University of Kansas, August 2015.

WALLER, David. The Perfect Man: The Muscular Life and Times of Eugen Sandow, Victorian Strongman. New York: Victorian Secrets, 2011.

“Woman Reducing Waist.” Advertisement. The Philadelphia Inquirer, 5 February 1956.

\section{ABSTRACTS}

Though only one-fifth of Americans do the recommended amount of daily physical exercise and most measures point to an extraordinary lack of fitness in the United States, the pursuit of regular exercise is widely celebrated not only as physically salutary, but as a sign of discipline, affluence, and virtue. Using popular press, institutional records, advice literature, advertisement, and memoir, this article explains how this was not always so. The pursuit of exercise evolved from a strange, suspicious subculture characterized by individual performance in the late nineteenth and early twentieth centuries to a more participatory realm represented by Muscle Beach in the 1940s and 1950s, establishing the foundation of today's "fit nation," a culture in which the pursuit of exercise is valorized as an ideal, but not equitably accessible.

Bien que seul•e un•e Américain•e sur cinq fasse de l'exercice tous les jours comme il est recommandé et bien que toutes les statistiques existantes mettent en évidence le manque d'exercice à l'échelle de la population nationale, avoir une activité physique régulière est pourtant unanimement célébré aux États-Unis, non seulement pour les bénéfices sur la santé qu'une telle pratique apporte, mais aussi car il s'agit d'un symbole de discipline, de richesse et de vertu morale. Fondé sur l'analyse de la presse populaire, d'archives institutionnelles, d'ouvrages spécialisés, de la publicité et de mémoires, cet article montre que cela n'a pourtant pas toujours été le cas. La pratique d'une activité physique trouve ses origines dans une sous-culture étrange, souvent considérée avec suspicion et fondée sur la performance individuelle, qui prend naissance

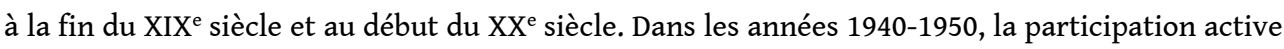


de toutes et tous devient un élément central du fitness avec, par exemple, le cas de Muscle Beach. Ces différentes étapes sont essentielles dans la constitution de ce que l'on peut appeler aujourd'hui une "nation en forme" (fit nation), c'est-à-dire l'émergence d'une culture dans laquelle la pratique d'une activité physique est promue en idéal, alors même que l'accès à cette pratique est profondément inégalitaire.

\section{INDEX}

Keywords: fitness, capitalism, business history, body image, exercise, physical fitness, beauty industry, physical education, inequality, youth culture, LGBTQ, feminism, gender, bodybuilding, Muscle Beach

Mots-clés: exercice, capitalisme, histoire des affaires, image de soi, activité physique, condition physique, industrie cosmétique, éducation physique, inégalité, culture de la jeunesse, LGBTQ, féminisme, genre, bodybuilding, Muscle Beach

\section{AUTHOR}

\section{NATALIA MEHLMAN PETRZELA}

The New School 